\title{
Eesti koorilaulu lõhestatusest nõukogude aastail
}

\begin{abstract}
Hain Rebas
Teesid: Instinktiivselt seome mõiste laulupidu Gustav Ernesaksa nimega. Miks see nii on, pole vaja lähemalt seletada, seda teab ja tunnetab kogu Eesti laulurahvas. Vähem teame aga sellest, kuidas, ja miks just temaga, ning milliste raskuste kiuste omal ajal kõik need asjad tema ümber just niimoodi sattusid, või õigemini sedamoodi toimetati.

Veelgi vähem tuntakse Eestis samaaegset väliseesti kultuurielu, näiteks väliseestlaste suurte laulupidude olemust, haaret ja patriootlikku mõju Juhan Aaviku, Eduard Tubina ning Eesti NSVs represseeritud Tuudur Vettiku ning tema Läände sattunud õpilaste Roman Toi ja Harri Kiisa liinis.

Kahtlemata lisasid Lääne väliseestlasi koondavad ja innustavad laulupeod midagi olulist väliseestluse vaimsusele ja püsivusele. Kindlasti oli ka väliseestlastel oma roll Eesti taasiseseivumisel veerand sajandi eest. Teiste sõnadega: on aeg korrastada arusaamisi eesti laulupidudest pärast Teist maailmasõda selles mõttes, et täpsustame ja suhtestame pisut nn Ernesaksa fenomeni ning räägime ka Saksamaal, Rootsis, Kanadas ja USAs toimunust.
\end{abstract}

Märksõnad: Juhan Aavik, Gustav Ernesaks, Harri Kiisk, laulupidu, Roman Toi, Tuudur Vettik, väliseesti

\section{Sissejuhatus}

Käesolev lugu peaks algama ühe ja lõppema teise üldtuntud fotoga. Lähtume 1938. aasta Tallinna laulupeo dirigentide rõõmsast kogupildist, kus üldjuhi Juhan Aaviku kõrval avastame Tuudur Vettiku, Alfred Karindi, Riho Pätsu, Verner Nerepi ja noore, veel tumedalokilise Gustav Ernesaksa. Lõpufotol näeksime aga kaarvankris kaht juba vanemat lõbusat meest pidulikus laulupeovalges rüüs. Kohe tunneme ära Gustav Ernesaksa ja tema kõrval torontolase Roman Toi. Pilt tehti 1990. aasta laulupeol Tallinnas. Nii algabki käesolev teema enne viimast maailmasõda ja lõpeb Eesti taasiseseisvumise ajal. Nende fotode põhjal küsime: kuidas lõhestati pärast Teist maailmasõda eesti koorilaul üle maade ja merede? 
Jah, hea on tagantjärele niimoodi pärida, sest tänu meie koorilaulu eestvedajatele nii siin kui seal ületati ametlikud kuristikud meie laulurahva eri kogukondade vahel juba ammu.

Teenekas musikoloog Urve Lippus on arvanud, et väliseestlastel on raske (et mitte ütelda võimatu) hoomata Eesti NSVs toimunut, ja seepärast nagu ei kõlbakski väljastpoolt tulnul neid asju arutada või neist kirjutada (Lippus 2007: 148-148). Nii lihtne see asi siiski ei ole. Iga Rootsis kasvanu tunneb mõistet hemmablindhet-kodupimedus. See tähendab, et igapäevased asjaolud saavad pikapeale nii tuttavaks, nii normaliseerunuks, et me ei panegi enam tähele, mis tegelikult toimub. Aastal 1975 õppis terve maailm tundma mõistet Stockholmi sündroom. See tähendab pantvangiks võetud, ähvardatud ja isoleeritud inimese üleminekut vägivallatseja poolele, pikapeale solidariseerumist röövliga ja tema meeskonna raudse reeglistikuga. Ajapikku hakkab vang vaenulikult suhtuma oma vabastajatesse, nagu tegi Stockholmis naispantvang Rootsi peaministri Olof Palme ja politsei suhtes. Või läheb ta edaspidi isegi koos gangsteritega panku röövima, nagu tegi juba 1974/75. aastal Patricia Hearst USAs. Säärasest sundolukorrast võib laiemas kontekstis aastakümnete jooksul areneda üldine tigedus, võõraste pelgamine, koguni nende vihkamine, nn vihakõned ja kasvõi see ksenofoobia, millest alles (jaanuaris 2016) kõneles president Ilves. Juba veerand sajandi eest märkis Ülo Matjus (tuntud ka I. Ronicuse pseudonüümi all), et meile on jäänud sovett kodusemaks kui väliseestlane. Nii oligi möödunud aasta (2015) Tartu rahvusülikooli aastapäeva konverentsi peateemaks, "keda ja mida pidada omaks ja võõraks".

Järgnevalt peaks selguma, miks just selline sissejuhatus. Eks ütle teaduse üks esimene reegel, et täispildi saamiseks tuleb asju vaadata ja uurida võimalikult mitme nurga alt. Eesti sõjajärgse koorilaulu ja laulupidude uuringuis on laiahaardelist, mitmekülgset ja süvitsi pürgimusi suutnud siiani pakkuda vähesed. ${ }^{1}$

Instinktiivselt seostub mõiste "laulupidu" kodueestlasel Gustav Ernesaksa nimega. Vähem teame aga sellest, kuidas ja miks just temaga, ning milliste raskuste kiuste omal ajal kõik need asjaolud tema ümber just niimoodi sattusid, või õigemini sedamoodi toimetati. Ernesaksast on kirjutatud küll riiulimeetreid, aga mainitud seoste teemat ei ole Eestis siiamaani puudutatud.

Veelgi vähem tuntakse Eestis samaaegset väliseesti kultuurielu, ${ }^{2}$ näiteks just väliseestlaste suurte laulupidude olemust, haaret ja rahvuslikku mõju. Ametlikult sai neid aastakümneid süstemaatiliselt eiratud, siis laimatud, tümitatud, ühesõnaga maha tehtud, veel 1980. aastatel. Rahvusliku üldhariduse mõttes oleks viimane aeg anda au tõele, korvata ka mainitud hariduse puudust. Teiste sõnadega tahan näidata, miks tuleks korrigeerida meie arusaamisi eesti laulupidudest pärast Teist maailmasõda selles mõttes, et analüüsime ja suh- 
testame pisut Ernesaksa fenomeni ja tutvustame lähemalt algselt ja peamiselt Saksamaal, Rootsis, Kanadas ja USAs toimunut. ${ }^{3}$

Kahtlemata lisasid väliseestlasi koondavad ja innustavad laulupeod ja ESTOd oma osa väliseestluse vaimsusele ja püsivusele, kindlasti oli väliseestlusel oma roll Eesti taasiseseisvumisel veerand sajandi eest.

\section{Ernesaksa fenomen}

Juba 1944. aastal kutsus ENSV/EKP juhtkond Jaroslavli evakueerunud Gustav Ernesaksa tagasi kodumaale korraldama järgmist, alles 1947. aastal toimunud laulupidu. Teatavasti sai Ernesaksast pikapeale laulupidude keskne kuju, armastatud Laulutaat.

Pole midagi parata, et Laulutaadi rahvuslikku vestiesist rikuvad mõned arvestatavad plekid, nagu näiteks NSV Liidu hümni pealt juba 1944. aastal parasjagu püüdlikult maha viksitud ENSV hümn "Jää kestma Kalevite kange rahvas". "Sellele järgnes 1947. aastal Ernesaksa esimene "Laul Stalinist". Suurküüditamiste, kolhoseerimise ja jätkuva metsavendluse 1949. aastal aga tuli Ernesaksalt kantaat Debora Vaarandi sõnadele "Laula, vaba rahvas!", mis oma küünilisuses mõjub lausa mõnitusena. Aga samas oli Ernesaks juba 1944. aasta sügisel loonud Lydia Koidula sõnadele seatud laulu "Mu isamaa on minu arm". Kolmandaks tuli temalt enamvähem samal ajal Juhan Liivi tekstile laul "Kui tume veel kauaks ka sinu maa"...

See, et Ernesaks oli võrsunud tagasihoidlikest oludest, ${ }^{5}$ sobis nõukogude võimuritele hästi. Veel paremini võis neile passida, et Ernesaksa üks vend oli sõja ajal põgenenud Läände ja sai pikapeale pankuriks otse New Yorgis, kuuldavasti isegi Wall Streetil. Teine vend oli võidelnud Eesti Leegioni ridades ja jäänud Sinimägedes kadunuks. Nõnda jäi isikuomadustelt väidetavalt aravõitu Ernesaks punavõimude poolt kergelt santažeeritavaks, aastakümneteks nagu pantvangiks. ${ }^{6}$ NLKPsse ta siiski ei astunud.

Seoses EK(b)P Keskkomitee kurikuulsa VIII pleenumiga 1950. aastal vallandas üks Eesti NSV kõige Moskva-kuulekam võimurite kamp (Ivan Käbin \& Co.) "natsionalismi" pähe teiste seas ka kõik vanemad eesti heliloojad ja dirigendid (EK(b)P VIII, A 1998-1999). Täpsustan: lavalt pühiti minema kolm neljast 1950. aasta laulupeoks ettenähtud üldjuhist. Neist oli staažikaim ja võimekaim Eesti esimene ja ainus kooridirigeerimise professor Tuudur Vettik, keda Käbin isiklikult süüdistas "Metsavendade hümni" loomises. ${ }^{7}$ Teised olid Alfred Karindi ja Riho Päts, kes olla sakslaste okupatsiooni ajal toimetanud sovetivastase lauliku (EK(b)P VIII, A 1999/1: 207). Konservatooriumi õppejõu 
ametist tagandati ka "Eesti lipu" ehk "Kaunistagem Eesti kojad" viisistaja Enn Võrk. See on kõik hästi teada lugu.

Vähem on ehk mõeldud sellele, et niiviisi lõi stalinistlik parteiladvik Ernesaksale kui Jaroslavli veteranile ja 1947. aasta Stalini preemia laureaadile puhtaks edaspidise karjääritee. Kõik ta võimalikud konkurendid koristati tee pealt eest, vaatamata sellele, et ka nemad olid 1948. aastal loonud püüdlikke laule Stalini ja nõukogude võimu auks (Lippus 2007: 148-149). Lavale jäeti üksinda särama Ernesaks. 1951. aastal autasustati teda järjekordse (esimene 1947) Stalini preemiaga lisaks 1950. aastal omistatud esimese Lenini ordenile. Teadagi kaasnesid selliste aumärkidega arvestatavad nomenklatuursed hüved, ühiskondlikud privileegid ja majanduslik kindlustatus. Süvenes ka sõltuvus võimuaparaadist.

Ent mille eest autasustati 1951. aastal Ernesaksa nii esiletõstetult? Vaevalt mõne üsna keskpärase sots-realistliku kaluriooperi eest, nagu on seda "Tormide rand" (1949). Kindlasti tõsteti Ernesaksa esile 1950. aasta (XIII) süngelt stalinistliku laulupeo eduka läbiviimise eest, kus vanade tegijate Vettiku, Karindi ja Pätsu asemel figureerisid uute eestvedajatena seltsimehed Tjumin ja Stepanov. Kuue lauluga kiideti Stalinit. Edaspidiste laulupidude repertuaarides puudusid autorite seast sõjaeelsed eesti koorilaulu klassikud nagu Karl August Hermann, Aleksander Saebelmann/Kunileid, Miina Härma, Peeter Süda, Juhan Simm, Adolf Vedro, Enn Võrk, Rudolf Tobias, Cyrillus Kreek ja Artur Kapp. Asemele tulid seltsimehed Dunajevski, Popovitš, Aleksandrov, Filippenko, Svešnikov, Muradeli, Vazovski, Holminov jpt (Ojamaa 2012: 50; Ojaveski \& Puust \& Põldmäe 2002: 124). 1960. aasta laulupeoks kasvas vene kooride suurus 2000 lauljani.

Samal ajal kui Eestimaal lauldi ülistuslaule Stalinile, kikerdas Tuudur Vettik kaugel vangilaagrites kuni 1956. aastani. ${ }^{8}$ Enn Võrk oli, nagu Ernesakski, õppinud Artur Kapi käe all ja loonud sellised laialt levinud helitööd nagu Eesti vahva lipulaul "Kaunistagem Eesti kojad" (mis muidugi paugupealt keelati), lüüriline "Helise ilma" ja romantiline "Ma lillesideme võtaks". Võrk pidi oma surmani 1962. aastal virelema Tallinnas klaverihäälestajana, tehes juhutöid Raplas ja mujalgi. Ka tema "Eesti on me isamaa" (1934) pandi põlu alla. ${ }^{9}$

\section{Muusikarahva omavahelised suhted}

Oleks muidugi sümpaatne, kui kusagil leiduks mingisugunegi mälujälg selle kohta, et punaste võimude poolt tugevalt soositud Ernesaks oleks 1950. aasta alguses kasvõi kulisside taga toetanud oma represseeritud ametivendi Tuudur Vettikut ja teisi. Aga selline märge puudub. Muidugi ei protesteeritud nende 
repressioonide puhul stalinisti ja pealekaebaja (Veskimägi 2005: 209) Eugen Kapi poolt juhitud ENSV Heliloojate Liidus. Endine, altpoolt demokraatlikult valitud Eesti Lauljate Liit (ELL), mida oli juhatanud professor Juhan Aavik, oli juba 1940. aasta suvel sundlikvideeritud. ${ }^{10}$ On siiski märkimisväärne, et seda enam kui sünget 1950. aastate heliloojate ja koorijuhtide ebasolidaarsuse teemat ei ole Eestis tänaseni puudutatudki. ${ }^{11}$

Muidugi teame kõik, et tollast karmi elu kujundati eelkõige Moskvast ja Moskva kohalike satraapide vahendusel. Vähe sellest. Samal ajal näitasid Nõukogude Liidu ja Eesti NSV julgeolekuorganid pidevat ja agressiivset huvi väliseestlaste ja nende organisatsioonide vastu. Neid luurati, santažeeriti, kompromiteeriti, infiltreeriti ja laimati süstemaatiliselt. ${ }^{12}$ Kus vähegi võimalik, püüti tekitada pahandusi ja õhutada sisetülisid. ${ }^{13}$

Stockholmis aga tellis kohaliku eesti ajalehe toimetaja Voldemar Kures Juhan Aavikult 1950. aasta suvel (21.-23. juulini) Tallinnas toimunud laulupeo arvustuse. ${ }^{14}$ Aavik kuulas raadioülekannet, analüüsis selle põhjal laulupeo repertuaari ja esitust ning kirjutas sellest ajalehes Stockholms-Tidningen Eestlastele. Ka pidas samuti Stockholmis tegutsev noor dirigent Harri Kiisk oma repertuaari valides pidevalt silmas Eestis toimuvat. Vettiku, Pätsu ja Karindi kurvast saatustest kirjutas ta juba 1954. aastal II Rootsi eesti üldlaulupeo kavaraamatus (Kiisk 1965: 239-245; Ojamaa 2012: 80 jj). Seoses eesti laulupidude 100. aastapäevaga 1969. aastal koostas Norrköpingi mees Johannes Äro soliidse ülevaate 100 aasta jooksul nii enne kui pärast sõdu, nii kodu- kui loomulikult ka välismaal toimunud laulupidudest (Meikop \& Remmelgas \& Äro 1969). ${ }^{15}$ Seda järelikult ütelda ei saa, et väliseestlased oleksid kodueesti kultuuriloomingut eiranud, või laimanud. Poliitilisel pinnal aga üksteist ignoreeriti (Toi 2007: 303). ${ }^{16}$

Kui mõni kodueestis loodud pala võeti ka väliseesti laulupeo kavasse, siis vastupidist ei toimunud mitte kunagi (Ojamaa 2012: 50). Läänes arenes asi vahepeal nii kaugele, et 1970. aastatel hakati vabariigi aastapäeva aktustel pisitasa laulma ka Ernesaksa "Mu isamaa on minu arm". Muidugi püsti seistes. Algus tehti Göteborgis. 1983. aastal, mil sealsele "Estivalile" kutsuti Ants Üleoja juhatatud Eesti Raadio ja Televisiooni segakoor Tallinnast täpselt samadel alustel kui teised eesti koorid, näiteks Inglismaalt. Viisakas kutse jäi ametlikult vastamata, nagu juba ette arvata võis.

Tekib küsimus, kas punavõimu poolt soositud Ernesaksa ja Eugen Kapi kasvatatud koolkond võis 1950. aastatel isegi ahistada mõnd kooriinimest, kes tahtnuks viljeleda hoopis teistlaadi muusikat? Eestist vastatakse: "Sellist inimest kindlasti ei olnud. Kõik teadsid väga hästi, mida oodatakse koorimuusikalt ja koorimuusikult ideoloogilises plaanis. Kui keegi oma hinges pooldaski teistsugust muusikat, siis ta avalikult oma maitse-eelistusi ei väljendanud. 
Kindlasti oli mõni selline, kellele meeldis religioosne koorimuusika, aga sellega tegelemise võimalustel oli kõva limiit peal: tohtis esitada mõni kord harva ja siis kas saksa või ladina keeles". ${ }^{17}$ Hästi tuntud näide on Rudolf Tobiase nelipühi põhitekstile rajatud "Eks teie tea" orelisaatega. Eesti keeles kanti seda kristlik-optimistlikku koraalkantaati muidugi ette väliseesti ringkondades, ja üsna tihti, Eesti NSVs aga üliharva, ja kui, siis ladina keeles "Nescite vos". See ei ole kultuurlooliselt sugugi halb variant, aga tavaeestlasele muidugi eeskirjade kohaselt arusaamatu. Täiesti keelati ära Cyrillus Kreegi sakraalne looming. Tema muusika toodi mikrofilmituna salaja Rootsi ja esitati Harri Kiisa eestvedamisel Stockholmis. Ning aastakümneteks lämmatati Eestis teiste heade laulude seas ära ka Konstantin Türnpu "Mu armas isamaa" meeskooridele (Aavik 1969: 170), tekst "Kaunistagem eesti kojad” autorilt Martin Lipult (1892).

\section{RAM Rootsis 1967. aastal}

Üks väliseestlaslik lisaaspekt kogu probleemistikule võiks olla järgmine ${ }^{18}$ : Kui Ernesaks 1967. aasta sügisel gastroleeris oma RAMiga Rootsis, esinesid nad ka Göteborgi ja Stockholmi kontserdihoonetes. ${ }^{19}$ Noorele algajale koorilauljale mõjus see imponeerivalt, hingematvalt, võimsalt! Mind koguni šokeeris kohaliku juhtiva lehe arvustuse pealkiri: "Kultiveeritud toorlaul"!20 Kusjuures Kuno Areng on kuskil tunnistanud, et ega kõik RAMi lauljad sel ajal nooti tundnudki. Et RAMi lauljaid valiti peamiselt häälematerjali järgi, kinnitab ka Urve Lippus (2007: 131).

Stockholmi kontserdi puhul 15. septembril olevat Stockholmi Eesti Meeskoor (SEM, 1944-) endale varunud esimese rõdu. Tuleb meeles pidada, et SEM oli tollal RAMist suuremgi koor, oli juba käinud USA-turneel (1963), ja koosnes, nagu RAMgi, valdavalt endistest rindemeestest. Aga kui RAMis domineerisid korpuse mehed, siis SEMis moodustasid ülekaalu RAMi endised vastased, s.t soomepoisid ja Eesti Leegioni võitlejad. Nii need eesti mehed seal siis seisid veidi enam kui 20 aastat pärast sõja lõppu: ühed laval, teised rõdul. Eesti laulu- ja lahingumehed kõik.

Kui RAMi kontsert lõppes, olevat SEM mühisenud rõdul püsti ja alustanud laialt Eesti hümni, s.t "Mu isamaa, mu õnn ja rõõm”. Tekkinud siis suur segadus ja probleem, et mis toimub, mida see tähendab ja - kas nagu neid kodus ette hoiatatud ikkagi "natsionalistlik provokatsioon", või mis? Kuno Areng mäletab, et kui dirigentidele ulatati pärast kontserti sinimustvalge lindiga lillekimbud, võetud need küll ilusti vastu, aga saadetud kohe lauljate teisse ritta, "nii et need esimesest reast välja ei paistaks" (Inno 1999: 59). Jäädvustatud foto aga näitab, kuidas Ernesaks ulatab "kõik oma kimbud" ilusa žestiga salongis istu- 
vale Marie Underile (Kiin 2009: 525-526). Kaunis ja julge samm punavõimude rõhutud pantvangi poolt.

Detailides erinevaid versioone on sellest markantsest õhtust mitu (vt ka Arjakas 2012). Siinse meenutuse iva peitub faktis, et RAMi juhatas küll suur Ernesaks, aga SEMi esimene ja pikaajaline dirigent oli Eduard Tubin. Ning pole tartlane, kümne sümfoonia, kahe ooperi ja ühe balletti jne looja Tubin eesti muusika ajaloos olnud kunagi kehvem või kahvatum tegija, kui märksa kohalikuma tegevusraadiusega Ernesaks. ${ }^{21}$ Nii andnudki Ernesaks uuemad, keerulisemad RAMi palad nooremate kolleegide Olev Oja ja Kuno Arengu juhatada.

Lisaks eelnevale pole ju Eduard Tubina koorilaulud Ernesaksa omadest sugugi vähem lauldavad, näiteks Betti Alveri tuntud teemal "Kaks saarlast" ja lõbusad meeskooripalad "Muhu kannanöör" ja Saaremaa kohanimedele leidlikult ehitatud "Sõmeralt Sõrmikule".

\section{Väliseesti laulupeod}

Oihh, aga nüüd turtsub kodumaine lauluinimene, et jajah, olgu Tubiniga kuidas on, aga Eesti laulupidude osas on Gustav Ernesaks olnud alati number üks! Siin nõustuks väliseestlane kohe: kindlasti number üks, aga Eesti NSVs. Küllap üritaks ta siinkohal tagasihoidlikult meelde tuletada, et eesti sõjajärgne kultuurielu ja nn laulupidundus ei piirdunud sugugi üksnes nn kodueestiga, ehk Eesti NSVga. Suurepäraseid laulupidusid pidas eesti rahvas juba diipiidena $^{22}$ Saksamaal ja põgenikena Rootsis. Seal loodi juba 1945. aastal Juhan Aaviku juhtimisel lauljate liit Eesti Lauljaskond Rootsis. Selleks ajaks töötasid juba mitmed eesti koorid kogu Rootsimaal, näiteks suured mees- ja segakoorid Stockholmis ja arvestatavad segakoorid Göteborgis, Norrköpingis, Hälsingborgis, Boråsis ja mujalgi.

Esimesed sõjajärgsed regionaalsed eesti laulupäevad toimusid 1946. aasta suve hakul Altenstadtis Saksamaal 8 koori ja ligi 300 lauljaga ja võidupüha raames Lääne-Rootsi Hindåsis. Suve lõpus esineti Saksamaal juba laulupeo mõõtmes Geislingenis 21 koori ja 882 lauljaga (Kool 1999: 777). Suuremad KeskRootsi eesti laulupäevad laulupeo eelproovina peeti Norrköpingis 1947. aastal ning Lääne-ja Lõuna-Rootsi suvepäevade raamis ka Hindåsis "vähemalt tuhande" inimesega ${ }^{23}$ Esimene Rootsi-Eesti laulupidu Stockholmis 1948. aasta suvel ühendas 21 koori ja 600 lauljat, lisaks neile veel eesti segakoor Lüübekist (Kangro 1976: 149).

Kanadas organiseeruti teatavasti hiljem. Esimesed eesti päevad koos laulupeoga peeti 1957. aastal Torontos. Tulid kokku 16 koori üle 500 lauljaga (Aun 1975: $589 \mathrm{jj})$. 
Jah, need on elutud, tuimad numbrid. Aga nende taga peitub igati arvestatav inimlik ettevõtlikkus meie laialipaisatud ja räsitud sõjapõgenike poolt. Kõike tuli alustada absoluutsest nullist, võõral maal, põlve otsas. Polnud ju väliseestlastel riiklikke asutusi, trükikodasid, palgatud eestvedajaid ega suurt, ülivõimast organisatsiooni ja propagandamasinat. Kõik tuli ise välja mõelda, omavahel kokku leppida, ise läbi viia: kõigepealt kohapeal, siis regioonis, siis üleriigiliselt, edasi juba ülemaailmselt ja korduvalt, üle maade ja merede. Loomulikult oli tervel sel kultuurilisel ettevõtlusel oma kindel poliitiline siht. Sealjuures kujutasid laulupeod ja rahvatants endast vaid laialt tähelepandavaid abinõusid otstarbele: juhtida rahvusvahelist tähelepanu Eesti olukorrale, nõuda vabadust Eestile.

Teatavasti leidis esimene ESTO aset Torontos 1972. aastal. Seal, esimesel Ülemaailmsel Eesti Rahvuskongressil, esindasid ligi 350 delegaati 200 organisatsiooni peaaegu kõigist eestlaste asukohamaadest vabas maailmas. Vabadusnõuet Eestile toetasid käetõstmisega 15000 Toronto raekoja platsile kogunenud eestlast. Laulupeo avataktiks oli Johannes Hiiobi harras ja pühalik "Ole ustav surmani”. Esinesid noortekoor 500 lauljaga, ühendatud 350liikmeline naiskoor, ühendatud 200liikmeline meeskoor, suur ühendatud segakoor ja pillikoor. Järgnes pidustuste finaal - valguspidu 20000 osavõtjaga. 1500 eesti noort pidasid skautide suurlaagrit Kotkajärvel, Muskoka metsades (Kreem 1998: 79, 91, 95, 99, 102). Teisele ESTOle, mis toimus Baltimore'is USAs 1976. aastal, kogunes 13 laste- ja 44 täiskasvanute koori, lavale mahtus 800 lauljat. ${ }^{24}$ Järgnevale ESTO 80-le Rootsi pealinnas Stockholmis, kus linna tsentrum oli - NB! ikkagi Brežnevi hiilgeajal - üleni kaunistatud sinimustvalgega, tuli kokku 90 koori 1200 lauljaga (Välme \& Milits 1980: 30). ${ }^{25}$ Seda ilusat üritust ilmus Eesti NSVst teiste seas nagu "üle vaatama" toosama Andrus Roolaht, kes on Rein Kordese nime all avaldanud Kodumaa kirjastusel ehk kõige räigemad paskvillid väliseestlaste vastu. ${ }^{26}$

Kalju Lepik Stockholmis on peamiselt tuntud luuletajana, aga elukutselt oli ta arhivaar, juhatas aastakümneid Rootsi Riigiarhiivi alla kuuluvat Balti Arhiivi. Tema andmetel ilmus Rootsi pressis 1980. aasta suvel Baltikumi teemadel 1. juulist kuni 10. augustini 626 kirjutist, mis on igati märkimisväärne. Väljaspool Rootsit kajastusid pidustused ja nendega seotud vabadusnõue ulatuslikumalt Lääne-Saksamaa üleriigilistes väljaannetes Frankfurter Allgemeine Zeitung, Die Welt, National-Zeitung, Süddeutsche Zeitung jne, samuti Šveitsis Neue Zürcher Zeitungis (Lepik 1981: 123). Järgnevale 1984. aasta ESTOle Torontos kogunes professor Karl Auna andmetel "kaugelt üle 20000 eestlase" (Aun 1985: 9). Loomulikult korjati raha ja sõideti-lennati need pikad vahemaad maha mitte selleks, et konkureerida Eestis peetavate laulupidudega, vaid puhtast kaasmaalaslikust taaskohtumisrõõmust ja kindlast tahtest 
näidata maailmale, et me eestlased ikka eksisteerime ja meil on oma kindlad arvamised, soovid ja nõuded!

Repertuaaride kohta ehk niipalju, et Geislingenis, Stockholmis ja Torontos ei lauldud Stalini suurusest ega Lenini vägevast sammust. Ei keelatud, salastatud ega võltsitud vanade eesti laulude tekste, nagu hakati tegema Eesti NSVs. Näiteks Mart Saare "Leelos" muudeti "ihkame ju ikkest lahti" möödanikuks, "ihkasime ikkest lahti" jne. Väliseesti suvekodudes ikka ja jälle lauldud Viktor Konstantin Oxfordi juba 1916. aastal loodud "Meil merivood..." tulevikku suunatud refrään "Saa vabaks Eesti meri" kaasajastati "Jää vabaks...". Väliseesti noorte seas populaarsed Enn Võrgu "Eesti on me isamaa" (1934) ja Juhan Aaviku juba 1938. aasta laulupeol esitatud "Õnne, Eesti rand ja saared" kadusid täiesti jne.

Veel: Stockholmi esimese (1948. aasta) laulupeo üldjuhina toimis sama mees, kes oli juhtinud ka viimast sõjaeelset, 1938. aasta XI rekordilise osalejate arvuga laulupidu Tallinnas. See oli Vabadussõja vabatahtlik, Eesti Lauljate Liidu esimees ja Tallinna Konservatooriumi kauaaegne direktor, professor Juhan Aavik. Teda kutsuti 1957. aastal honoris causa ka esimeste Kanada eesti päevade laulupeo juhatajaks. Orkestrit juhatas Stockholmis Verner Nerep, ka tema oli Tallinna laulupeo üldjuhi kogemustega mees.

Juhan Aaviku kohta ei saaks kuidagi väita, nagu olnuks ta eesti muusika ajaloos oma õpilasest Gustav Ernesaksast pisem või nigelam. Vastupidi: Aavik oli, nagu tunnistab Ernesaks oma mälestustes, tema suur eeskuju (Ernesaks 1977: 28). Aavik juhatas Stockholmis veel aastaid omanimelist suurt ja kõrgetasemelist segakoori (asutatud 1944). ${ }^{27}$

Väliseestlaste seas, vähemalt Rootsis, lauldakse Eesti Vabariigi aastapäeva aktustel ikka, püsti ja püstipäi, Aaviku 1933. aastal Eestis loodud "Hoia, Jumal, Eestit”. Ka seda laulu eirati Eesti NSVs ametlikult, kuni Roman Toi selle Ants Üleoja abiga 1990. aastal Tallinna laulupeole viis ja lasi seda hardunud rahva nõudel korrata kolm korda (Toi 2007: 339). Ning pole see Aaviku südamlik koraalitaoline palve nõrgem ega kehvemalt lauldav kui isegi Ernesaksa nn laulupeo hümn "Mu isamaa on minu arm". Nii ongi "Hoia, Jumal..." mõne viimase aastakümne jooksul leidnud tagasitee iga soliidse eesti koori põhirepertuaari. ${ }^{28}$

Altenstadtis ja Geislingenis astus oma esimesi samme Laulutaat II aunimetuse suunas Roman Toi, kes lõikas hiljem loorbereid Montrealis, Torontos, ülemaailmsetel ESTOdel ja lõpuks ka Tallinna laulupidudel (Toi 2007). Ja Stockholmis algas 1950. aastatel Harri Kiisa mitmekümneaastane tähelend dirigendina ning eesti muusika mõjuka edendaja ja tutvustajana. ${ }^{29}$

Pealegi olid Toi ja Kiisk, nagu ka Göteborgi ja Stockholmi Eesti Meeskooride pikaajalised dirigendid Eero Tarjus ja Lembit Leetma, ja ma arvan, et ka New Yorgi suure Eesti Meeskoori dirigent Manivald Loite, olnud Tuudur 
Vettiku õpilased. Nagu näitas Harri Kiisk, suutis murdmatu Vettik veel pärast naasmist vangilaagritest, oma nn Lenini lauluga (1947/1978) pilada kehtivat süsteemi (Kiisk 1982: 6-8).

Võttes otsi kokku on raske ette kujutada sirgjoonelisemat kontinuiteeti eesti sõjajärgses koorimuusikas kui läbi Juhan Aaviku, Eduard Tubina ja Tuudur Vettiku. Ja järgmises generatsioonis läbi Olav Rootsi, Roman Toi ja Harri Kiisa. Niimoodi kindlustati, julgen väita, väliseesti soliidseim mõeldav eesti koorilaulu tase ja sellega kaasnev, võltsimatult normaalne eesti rahvuslik hoiak.

Ida pool Läänemerd pidi aga kõik jääma Moskvast määratud päitsetesse. Paneme tähele, et samal 1950. aastal, kui loodi Uues Maailmas suured New Yorgi ja Toronto eesti meeskoorid, esitati ENSV laulupeol esimeste lauludena A. Aleksandrovi "Kantaat Stalinist", G. Ernesaksa "Laul Stalinile" ja E. Kapi lausa pilkav kantaat "Rahva võim". Järeldame niisiis, et puhtalt eestipärane koorilaulu traditsioon jätkus eeskätt väliseestlaste seas, nimelt Saksamaal ja Rootsis, hiljem ka Kanadas ja USAs ja mujalgi, ning vähem anastatud ja totalitaarses Eesti NSVs. Alles mõni aasta pärast NLKP XX kongressi 1956. aastal hakati Eestis aeglaselt, nagu samm-haaval lõdvendama ka muusikute ohje.

Tekib küsimus, et kui väliseesti lauljad ja koorid valisid ise oma dirigendid, juhatused ja eeskavad ning otsustasid enesestmõistetavalt ise, millistest üritustest osa võtta või ka mitte - kes juhtis tegelikult laulukoorindust totalitaarsesse NSV Liitu hõivatud Eestis? Vaevalt tõi Gustav Ernesaks omal isiklikul initsiatiivil kõik need vene koorid ja parteilaulud näiteks 1955. ja 1960. aastate laulupidudele? (Vrd Labi 2011: 109-121.)

Rootsis on Harri Kiisk (1922-2000) ja taasiseseivunud Eestis on Kristin Kuutma jt korduvalt uurinud laulupidude ajalugu ja mõjusid (Ojamaa \& Kiisk 2012; Kuutma 1996, 1997; Brüggemann \& Kasekamp 2014: 259-276; Allandi 2014). Urve Lippus on tegelenud eesti (ENSV) meestelaulu traditsiooniga (2007). Rein Säde suutis avaldada isegi kriitilise dokfilmi esimeste sõjajärgsete Eesti NSV laulupidude, eriti 1969. aasta juubelilaulupeo kohta. Täpsemalt käsitles ta Jüri Müüri ja Hando Runneli laulupeo filmi "Laulev eestlane" ärakohitsemist võimudele meelepärasemaks "Leelo" (Säde 2007). Kanada eestlaste panust meie laulupidudesse on soliidselt tutvustanud Triinu Ojamaa (2011). Samalt autorilt on oodata lähemat ka Juhan Aaviku tegevuse kohta Stockholmis. Vaid mõnevõrra on taasiseseisvunud Eestis analüüsitud Eesti NSV 1950. aastate üldisemat kultuuripoliitikat (Kuuli 2002, kusjuures muusika ja kooride elu-olu kohta on autoril öelda üpris vähe; vt ka Saueauk 2015). Siin ootab uurijaid suur ja lai tööpõld. 


\section{Ernesaks, Viies ja Lentsman}

Kuid uuritud pole laulupidude konkreetset seost NLKP ja KGBga. Ei tea, kas seda küsimust on püstitatudki? Järelikult puuduvad pädevad vastused ENSV laulupidude tegeliku juhtimise kohta. Nii tuleb uudishimulikule inimesele soovitada põhiallikaid. Need on vastavad kaustad kompartei ja julgeoleku arhiivides ning Ernesaksa isiklik toimik, mida hakati pidama juba sõja ajal Jaroslavlis. Võrrelda tuleks neid vähemalt kahe Ernesaksa kaasaegse kõrgema parteifunktsionääri papkadega. Esiteks seaks luubi alla ENSV aseharidusja asekultuuriministri ning eriti väliseestlastele n-ö spetsialiseerunud Raoul Viiese (1925-1985) toimiku. ${ }^{30}$ Ja kõrvutaks seda eeskätt Venemaa eestlase, korpuse politruki ja aastakümneid agitpropi ja EKP Keskkomitee sekretärina ja 2. sekretärina, eriti hariduse ja ideoloogilise kasvatuse alal, tegutsenud Leonid Lentsmani (1915-1996) omaga. ${ }^{31}$

Tolle vahel ägedalt esineva (H. Meri 2008: 312) ja eesti kultuurielu jäigalt venestava (Grabbi 2010: 110, 205, 126) Lentsmani tegemisi 1950. aastate keskel on ilmekalt kirjeldanud Siberist parajasti naasnud Jaan Kross (2003: 501, 309, 511, 519, 520, 548, 581, 582). Armu andmata nimetab Heinz Valk (2010: 183) Lentsmani "vintskeks stalinistiks ja erakordseks puru-tagurlaseks". Jah, kui sobis, vaenas Lentsman eesti juute, parastas juba mahavõetud Nikolai Karotamme ja haukus juba mahalastud Beria kallal. Uue võimaluse korral aga lömitas energiliselt Moskva ülemuste ees (Veskimägi 2005: 252-253, 292; vt ka Liivik 2009: 405-414). Võib vaid aimata, kuidas säärane tüüp võis mõjuda niikuinii nõrga närvikoega ja oma kahe venna tõttu kergelt santažeeritavale Ernesaksale...

Aga täitsa erilist huvi pälvivad tol ajal Ernesaksa läheduses korduvalt esineva "saatja" (käendaja?) Raoul Viiese suhted mitte ainult EKP tippude ja Lentsmaniga, vaid ka nn julgeolekuorganitega. KGBs tunti Viiest ka agent "Maiski" nime all (Jürjo 1996: 207). Enam kui tähenduslik võib olla vaid 30aastase Viiese seltskonna kuuldes Ernesaksale purjuspäi näkku paisatud lause: "Mina sind ju selliseks jõulupuuks tegingi!" J2 Järelikult: Ernesaks kui kompartei ja julgeoleku väidetav “jõulupuu”? Enamvähem samal ajal lõi Ernesaks oma Juhan Liivi sõnadele südantlōhestava "Lumi tuiskab, mina laulan, laulan kurba laulukest”. Jah, selle sünge aja näilistes kokkusattuvustes leidub järeltulevatele põlvedele ainet järelemõtlemiseks küll ja küll.

Küllap ütleb Viiese reljeefne väljendus tolleaegse nomenklatuuri kavade ja mentaliteedi kohta nii mõndagi... Samas on Jaan Kross eraviisiliselt liigitanud Viiese "nende väheste koputajate hulka, kes pole lõpuni sead" (E.-N. Kross, meilitsi 5. detsembril 2012). Nii et üle dramatiseerida ka ei maksa. Seltsimees Viies esineb ka Elo Tuglase mälestustes. Pärast Tuglaste põlu alt pääsemist 
"saadab" ta nimelt Ernesaksa esimest korda Tuglastele külla Nõmmel. Kui allikaks võtta täpne Elo Tuglas, ei olnud ettevaatlik Ernesaks külastanud ikka veel põlu all (1950-1955) olevat Tuglast kordagi. Aga toosama Viies "saatis" hiljem Tuglaste juurde ka Soome kultuuritegelasi, nagu oodata võis (Tuglas 1993: 251, 252; vrd Inno 1999; Lippus 2007: 131)...

Raoul Viiese rapordid Ernesaksa kohta ja tema ülemuse Leonid Lentsmani vahekorrad vastavate Moskva asutustega selgitaksid nii üht kui teist selle kohta, mis moodi 1950. aastatel ja hiljemgi Moskva tegelikult jagas kultuurpoliitilist piitsa ja präänikut Tallinnale, ka koorilaulu alal. Ja mismoodi kohalikud ülemused nagu Lentsman jt edasi toimetasid.

\section{Koidula ja Ernesaksa "Mu isamaa on minu arm" Göteborgis}

Teadaolevalt lauldi väliseesti ringkonnis ametlikult Koidula ja Ernesaksa "Mu isamaa" esimest korda Göteborgis. Selle esitas kohalik Eesti Meeskoor ühel Eesti Vabariigi aastapäeval juba 1970. aastate alguses(? ${ }^{33}$ Burgårdeni reaalkooli aulas Göteborgis. See väga varajane Ernesaksa retseptsioon, pealegi Eesti Vabariigi aastapäeval, äratas oma kindlat tähelepanu, lõi laineid ja tõi ka kriitikat, eriti Stockholmi ja küllap ka Toronto "kindlameelsetes" eesti seltskondades. Aga mujal seda aktsiooni ka kiideti - olenes muidugi sellest, kuidas keegi kodueesti oludest informeeritud oli ja neisse ning väliseesti juhtkondade üldiselt eiravatesse hoiakutesse suhtus.

Asi algas sellega, et Göteborgis elunev kunstiteadlane Rain Rebas oli Eesti raadiost vist päris juhuslikult (sest eriti muusikahuviline ta ei olnud) kuulnud 1969. aasta juubelilaulupeo tunneteküllast ülekannet, kus lauljad lõpus keeldusid lavalt alla tulemast ja rahvas lauluväljakult lahkumast. Ja kus ikka ja jälle lauldi, ümiseti, nuteti koos sedasama Koidula ja Ernesaksa "Mu isamaa on minu arm”. See sündmus veenis Rebast lõplikult kodueestlaste jätkuvas soojas rahvustundes, milles väliseestlaste seas ju sel ajal siinseal kaheldi. Sealt ammutas Rebas inspiratsiooni aktiivsusele. Ta veendus, et meie, väliseestlased, peaksime solidaarsusest rõhutud eesti õdede-vendadega laulma just sedasama Ernesaksa "Mu isamaa on minu arm", mis oli tõusnud rahva seas vahepeal nagu uueks hümniks. Aga seda ei peaks tehtama niisama, siinseal omaette, vaid kohe ametlikult, julgelt, uhkelt, nimelt Eesti Vabariigi aastapäeva aktusel. Niimoodi saaks korralikult ja selgelt markeeritud rahva jätkuv ühtsus, solidaarsus välis- ja kodueestlaste vahel. Ning Koidula ja Paciuse hümn "Mu isamaa, mu õnn ja rõõm”, tuleks aktuse lõpus niikuinii, üldlauluna, nagu ikka. 
Koos poja Ahoga, kes tollal laulis GEMis bassi, veensid nad kahekesi meeskoori dirigenti Eero Tarjust võtma Ernesaksa laul koori hooaja kavasse ja ühtlasi vabariigi aastapäeva aktuse programmi.

Aktuse puhul leppisime R. Rebasega omavahel kokku nii, et istume saalis üksteisest eemal, tema, pikk mees, ees, mina strateegiliselt keset saali, hästi nähtaval mõlemad. Ja kui alustati lavalt "Mu isamaa...", tõusime kahekesi püsti, lootuses, et küll rahvas näeb, ei jäta meid üksi ja tuleb ilusti järele... Tuligi. Alguses küsivalt, kõheldes, siis - mühisedes. Oli ülev tunne... "sada surma ma, su pärast suu-ree-maa"... liigutav, hingele hea. Igatahes eesti pagulasajalooline suursündmus, olgugi suhteliselt väikeses, nagu oma inimeste mastaabis. Ei hakanud meist keegi selle peaaegu et intiimse toiminguga kusagil eputama, seda suure kella külge riputama. Aga kunagi pidi saama ka see lugu ära räägitud.

\section{Mis arvati Tartus?}

Huvitav oleks siinjuures teada, mida mõeldi nende 1950. aastate tallinlike võimuvõtete kohta ülikoolilinnas Tartus, kust tuli ms ka kohalikku Meestelaulu Seltsi meeskoori juhatanud Eduard Tubin? Seal töötas ju teinegi kõva, isegi vabariigieelse traditsiooniga meeskoor, nimelt TAM (asutatud 1912), eesotsas emeriteeritud Juhan Simmi ja eriti Richard Ritsinguga, mõlemad eesti vanima, sinimustvalge organisatsiooni EÜSi vilistlased. Mis arvasid? Millega tegelesid? Ning tekkis Tartusse veel üks arvestatav meeskoor - Gaudeamus, mida juhatas Tuudur Vettiku eriline jünger Roland Laasmäe (vt Randjärv 2013). Kuidas reageeriti Tartus? On nimelt teada, et TAMis viljeleti ka süngeimal soveti ajal endist, s.t eestiaegset akadeemilist suhtluskultuuri ja stiili. Ja eks ole eriti eesti meeskooridel alati olnud eriline rahvuslik ühiskondlik roll? Vaevalt on Tartus säilitatud märkmeid nende vanade, süngete ja lausa kardetavate aegade kohta, aga suulist traditsiooni edastamaks uurijatele peaks ehk veel leiduma?

\section{Kontrafaktika}

Spekuleerida võib ka teemal, mismoodi oleks mõjutanud eesti kooriloomingut, -organisatsiooni ja kooride kõla, kui oma RAMile pühendunud Ernesaksa asemel oleks jäänud segakooride edendaja ja Eesti esimene dirigentprofessor Vettik eesti laulukoorinduse etteotsa. Kas oleks nihkutud eemale RAMi tollal ikkagi Ernesaksa "Hakkame mehed" stiilis ida-euroopalikust "kultiveeritud toorlaulust", mille peamine kõla oli mürisevalt "mehine"? ${ }^{34}$ Ja oleks ehk suundutud hoopis lüürilisema, skandinaaviapärase (M. Wöldike 1897-1988, E. Ericson 
1918-2013 stiilis) täpsuse ja kõlakerguse suunas, nagu on vist ainuvõimalik Vettiku "Nokturniga"? Tähendab, nagu tõi Eesti kultuurimaastikule veidi hiljem Kuno Arengu ja Ants Üleoja juhatatud Tallinna Kammerkoor? Ning mida jätkas suure menu ja eduga Eric Ericsoni mõju all tema järglane Rootsi Raadiokoori (Radiokören) juhatajana Tõnu Kaljuste oma Tallinna Filharmoonia Kammerkooriga?

Ning kas oleks Vettiku juhtimisel elavnenud ka dirigeerimine ise, analüüs, õpetamine, levinud tema enda rõhutatud, dünaamiline tõlgendus koos minimalistliku löögitehnikaga? Teenekas Ants Üleoja mäletab (Randjärv 2007: 187-205) ka, kuidas talle kui noorele algajale muusikainimesena soovitati 1956. aastal minna Tallinnasse: "katsu Vettiku juurde õppima saada, teiste juurde pole mõtet minna. Ega seal Ernesaksa juures midagi ei õpi”. Ja kus Taišeti laagrist naasnud Vettiku juures Tallinnas Konservatooriumis õpiti Üleotsa sõnutsi juhatama peamiselt "Mart Saare lugusid, Artur Kappi ja Kreeki", kes pole 1950. aastate ägedalt venestavas kontekstis sugugi juhuslikud nimed. Üleoja refereerib lugu, kuidas Vettik, kui ta 1950. aastal teel kaugele itta veel Narvas vanglas istus, teinud vangide seas dirigenditööd. Pannud kokku meeskoori ja oli müüri taga, just siis kui RAMi mehed sealkandis ringi jalutasid, laulnud oma seltskonnaga "eestiaegseid laule". Vaevalt oli see juhuslik.

Üldse peab Üleoja Vettikut optimaalseks laulupidude üldkoori juhatajaks. "Kõikidest kõige paremini läks suur koor Vettikuga kaasa. Ta oli absoluutselt ideaalne laulupeo dirigent [---] keegi ei ole laulupeo koori niimoodi juhatanud nagu Vettik" (Randjärv 2007: 190-191, 194, 196, 205). Niisiis kaotas eesti muusika- ja koorielu Vettiku radikaalse eemaldamisega aastal 1950 midagi väga olulist.

\section{Kokkuvõte}

Kogesime NLKP võimuaparaadi ja tema kohalike eesti kaasajooksike poolt pealesurutud aastakümnete lõhestatust kahe eesti kogukonna vahel. Aga just koorilaulu ja laulupidude kaudu suudeti Eestis kõige ametliku nõmeduse ja labasuse kiuste säilitada ja arendada seda, mida lähemalt defineerimata ja häbenemata nimetame positiivseks rahvuslikuks eestluseks.

Nagu murelik papa Jannsen ärkamisajal, pidi kindlasti parasjagu santažeeritav aga sihikindel Gustav Ernesaks olema mees, kel tuli pidevalt käia munadel, et saaks kuidagimoodigi läbi viidud kõrgemad ja kaugemad sihid. Et tal see üle kivide ja kändude ikkagi õnnestus, selle eest on taastatud vabariik tänanud teda soliidsete riiklike matustega (1993), rahvas aga Laulutaadi aunimetuse ja meeldejääva kujuga Lauluväljaku nõlval. 
Väliseesti järjepidev koorilaulutraditsioon seisab aga selgelt Juhan Aaviku ja Eduard Tubina, kuid eriti Tuudur Vettiku õlgadel, nagu on korduvalt tõendanud koorijuhipõldudel siin- ja sealpool Atlandi ookeani mõjukalt töötanud Harri Kiisk ja Roman Toi. Alles 1990. aastate alguses said mõlemad eesti koorilaulutraditsioonid kokku sulatatud.

Jah - ega teadmine sellest, kust me tuleme ja kuidas meid vahepeal mis võtetega lahutati, paha tee. Oleks ikka narr, nagu tavatses ütelda Jaan Kross, kui me faktidele ja neilt tuletatud soovidele tähelepanu ei osutaks.

Ongi viimane aeg, et taastatud Eesti Vabariik vääristaks väliseestlaste vankumatult rahvuslikku ja kvaliteetset laulupeotraditsiooni. Päris loomulikult peaksid mitte ainult kodumaal, vaid olude sunnil ka välismaal elavate eestlaste laulupeod ja ESTOd kuuluma UNESCO poolt 2003. aastal kaitstud maailmapärandisse ${ }^{35}$... Siin oleks praegusel Eesti kultuuribürokraatial paras tegutsemisülesanne!

Muide, tulles tagasi alguses viidatud foto juurde, Gustav Ernesaks ja Roman Toi 1990. aasta laulupeo kaarvankris, meenub, et sel suvel (2016) ületab maestro Roman Toi Torontos loodetavasti 100 aasta lävepaku... Ruumi küll ja küll ju, seal mõtliku pilguga Ernesaksa kõrval Tallinna Lauluväljaku lahedal nõlvakul!

\section{Märkus}

Artikkel on edasiarendus 14. septembril 2015 Tallinna Ülikoolis rahvusvahelisel konverentsil "Eesti kultuuri suurpeod maailmapärandis" peetud ettekandest.

\section{Kommentaarid}

1 Hiilgav erand on Triinu Ojamaa Tartus.

${ }^{2}$ Hiilgavaks erandiks Janika Kronberg ja Eesti Kirjandusmuuseumi töötajad, projekti Methis kaastöölised. Kirjanduse puhul vrd eelkõige H. Grabbi kriitilist arvustust "Pagulasajakirjanduse ajalugu veel ühe pilgu läbi. Vaade Välis-Eestist" ja seal refereeritud kirjandust (Grabbi 2011). Eestis mitteretsepteeritud historiograafia puhul vt nt Rebas 1978. Sarnaseid näiteid võiks tuua tosinate kaupa.

3 Olgu siin lisatud, et eesti laulupidusid on peetud ka Inglismaal, Austraalias ja UusMeremaal.

4 Sellest Johannes Semperi 1944. aastal loodud kommunismi ülistavast tekstist võeti 1956. aastal välja ülistus "suurele Stalinile", alles jäeti aga kiidulaul sovetlikule süsteemile.

5 Sündis Perila külas Peningi vallas Harjumaal. 
6 Andres Laasik, kes teinud Ernesaksast dokfilmi "Laulutaadi hümnid", väidab põhjendatult, et "hirm saatis Gustav Ernesaksa elu lõpuni" (ERR Uudised, 10.12.2008); vt ka Olev Remsu (2009) põhjalikku arvustust Sirbis ("Seest siiruviiruline, pealt punakarvaline").

7 Laulikus "Lemmiklaulik. Algkooli I ja II klassi lauluvara", mille koostas Riho Päts (Eesti Kirjastus 1942), esines tõepoolest üks "Metsavendade laul anno 1941", mille oli 1930. aastatel "muistse vabadusvõitluse teemadel" seadnud Vettik.

8 Talle määras vastav tribunal kurikuulsate paragrahvide 58-1a ja 58-10 põhjal kokku 25 aastat. Vettiku laagrielu kohta vt lähemalt Laine Randjärve intervjuud A. Liikiga (Randjärv 2012: 207-213).

9 Seda lauldi kuni 1970. aastateni meeleldi Rootsi-eesti suvekodudes Kungla, Ojamaa ja ELA Kärr-Sämstadis.

${ }^{10}$ ELL liideti 1940. aastal Eesti Töölismuusika Liiduga, mille tegevus peatselt lõpetati.

${ }^{11}$ Veljo Tormis via Triinu Ojamaa, meil autorile, 11. detsembril 2012.

${ }^{12}$ Nädalaleht Kodumaa algusest saadik; vt ka Rein Kordese alias Andrus Roolahe publikatsioone; Jürjo 1996. Sääraseks tööks kasutas NSVL nn julgeolek täisrepertuaari, see tähendab pagulasspioone (Suurväli, "Jurist", "Borets"), infiltraatoreid ja provokaatoreid (Hiir, Laht, Haman/Tuldava), õnnetuid santažeeritavaid, kojumeelitajaid (VEKSA oma laialt levitatud ja tasuta kojusaadetud Kodumaaga), mitmes kaliibris laimajaid (Kordes-Roolaht), ja NSVL Stockholmi saatkonna eesti soost nuhkijaid/ raporteerijaid (Veber, Toom, Kolk, Mikkelsaar/Kedrov, hiljem Pohla, Made, Rahumaa). Nende ettekanded Stockholmist Moskvasse tulid töödeldud kujul tagasi Tallinna. Sedaviisi maandusid küllap päris valusad teadmised Toompea, Pagari tänava ja Kadrioru tipp-ešelonides paindumatutest kaasmaalastest piiri taga ning nende vaba, iseseisva Eesti poliitilistest eesmärkidest ja hästiorganiseeritud kultuurilistest kavadest; loomulikult ka koorilaulu alal... Ka seosed Stockholmi, Toronto, New Yorgi ning Moskva ja Tallinna liinil võiksid kunagi sattuda ajaloo uurijate luubi alla.

${ }^{13}$ Stockholmi Teataja toimetaja Harri Kiisk rääkis kord, et kui Stockholmi eestlaskonnas tekkis mingi ähmane rahutus, tasus alati helistada lätlastele ja küsida, kas ka neil on samamoodi. Kui lätlased jaatasid, oli asi selge...

${ }^{14}$ Ilmunud Stockholms-Tidningen Eestlastele juuni lõpus või juuli alguses 1950. aastal (Triinu Ojamaa andmeil).

15 Tänud T. Ojamaale info eest!

${ }^{16}$ Karm reaalsus oli hoopis teine. Aastail 1963-1972 anti Stockholmis välja Eesti saatusaastad 1945-1960 I-VI. Ja Eesti NSVs anti nn väärikas vastulöök väliseestlaste suurele koguteosele Eesti riik ja rahvas II maailmasõjas (Stockholm 1954-1960, I-XII): esiteks juba 1960. aastatel mõne sarnase kujunduse ja trükiga, aga Nõukogude liimist haisva, tselluloosil trükitud "apokriivaga", tähendab nummerdatud pseudolisaköidetega, lisaks ilmus veel Leonid Lentsmani "toimetatud" koguteos Eesti rahvas Nõukogude Liidu Suures Isamaasõjas 1941-1945 (Tallinn 1971); järelikult - jälgiti üksteist mis suudeti.

17 Triinu Ojamaa vahendas Veljo Tormise ja Kuno Arengu andmeid autorile 11. detsembril 2012.

18 Tänan Jüri-Karl Seimi Stockholmis täpsete meeldetuletuste eest. 
19 Juba varem olid Göteborgi (Lisebergi) külastanud ka võimsad New Yorgi ja Toronto eesti meeskoorid, mõlemad loodud 1950. aastal, juhatajad Manivald Loite ja Roman Toi.

20 "Kultiverad råsång" rubriigi all võttis RAMi kontserdi kokku Göteborgs Handels- och Sjöfartstidningeni respekteeritud muusikakriitik Björn Johansson.

${ }^{21}$ Vt ka K. Areng: "Ernesaks oli küll tugev eesti muusikas, aga maailma muusika taust oli kaunis auklik" (Klaats, Maaleht, 22.07.2004); Ernesaksa suhtelist muusikalist piiratust kinnitavad ka Olev Oja, Vello Mäeots ja Kuno Areng (vt Inno 1999: 45 jj). Näiteks polevat talle istunud Veljo Tormise lood (Aarma 2014).

${ }^{22}$ Diipii = D.P. $=$ displaced person, põgenik sõjajärgsel Saksamaal.

${ }^{23}$ Korraldasid Alingsåsi Eesti Selts, Alingsåsi ENMKÜ, Alingsåsi Eesti Segakoor, Boråsi Eesti Selts, Boråsi skaudid ja gaidid, Göteborgi Eesti Selts, Göteborgi ENMKÜ, Göteborgi Eesti Segakoor ja Göteborgi rahvatantsurühm. Korraldavat komiteed juhtis esimehena Valdur Leinveer Alingsåsi Eesti Seltsist, sekretäridena toimisid Hans Lupp Boråsi Eesti Seltsist ja Julius Ridal Göteborgi ENMKÜ esindajana. Peokõne pidas Eduard Riisna. Huvitaval kombel rändasid kõik neli peategelast edasi üle Atlandi: Leinveer Ontariosse, Riisna Torontosse, Lupp Torontosse ja Ridal Montreali, kus nad silmapaistvalt jätkasid oma rahvuslikku tööd. Jumalateenistust pidas pastor Teodor Tallimeister, ühendatud segakoore juhatasid Harri Truus ja J. Klaassen, Göteborgi rahvatantsijaid Paula Roove, Boråsi rahvatantsijaid Hans Lupp, ühendatud rahvatantsijaid J. Klaassen. (Lääne-Rootsi eestlaste suvipäev Hindåsis 1946)

${ }^{24}$ A. Valge autorile meilitsi 26. augustil 2015.

${ }^{25}$ Koorid ja isegi kõik lauljad on loetletud K. Lepiku toimetatud kogumikus ESTO 80, Stockholm 1981, lk 99.

${ }^{26}$ Nagu rääkis mulle Valter Soo, kes oli 1930. aastate lõpus töötanud koos Roolahega Riiklikus Propagandatalituses.

${ }^{27}$ Seda teemat uurib parajasti Triinu Ojamaa Tartus.

${ }^{28}$ T. Ojamaa andmetel avaldati "Hoia, Jumal" pärast sõda esimest korda 1988. aastal Alo ja Mare Põldmäe koostatud laulikus Eesti isamaalisi laule.

${ }^{29}$ Vahetult enne 2012. aasta jõule ilmus Triinu Ojamaa kirjutatud Harri Kiisa biograafia (Tartu 2012).

${ }^{30}$ Viies oli aastail 1954-1957 ENSV haridusministri asetäitja, alates 1957. aastast töötas Välismaaga Sõpruse ja Kultuurisidemete Arendamise Eesti Ühingus, millest kasvas lõpuks välja VEKSA, oli aastail 1961-1971 ühingu esimees, 1971-1981 ENSV kultuurministri asetäitja, seejärel I asetäitja.

${ }^{31}$ Lentsman oli aastail 1950-1951 ENSV haridusminister, 1951-1953 EKP KK sekretär ja ideoloogia osakonna juhataja, kuni 1964. aastani II sekretär, aastail 1964-1974 EKP KK sekretär.

${ }^{32}$ Kaasaegsed andmed (Kuno Areng), meilitsi vahendanud Triinu Ojamaa Tartus.

${ }^{33}$ See võis olla ka hiljem, pärast 1975. aasta XVIII üldaulupidu.

${ }^{34}$ Selle kohta niipalju, et üldiselt on teada, et noorele Ernesaksale imponeeris Slovakkia meeskooride stiil ja kõla. Kui Göteborgi Akadeemiline Meeskoor (AK) külastas 2008. aasta detsembris Tartus TAMi, peeti ühiskontsert Tartu ülikooli aulas. Kuna TAM valmistus ette Gustav Ernesaksa 100 aasta juubelikonkursile, esitas ta kontserdil 
peaasjalikult Ernesaksa loomingut, millega mina eestlasena olin harjunud ("kodupime"?) ega osanud, ei kujutanudki ette reageerida nagu rootslastest lauluvennad: "Mis asi? Nii üksluised, omavahel sarnased, päris igavad laulud!" Ning keeldus AK uus, erakorraliselt andekas koorijuht dirigeerimast Ernesaksa "Hakkame mehed", mida AK oli varem laulnud (eesti keeles) küll ja küll. Cyrillus Kreegi, Mart Saare, Tuudur Vettiku ja Veljo Tormise loomingut juhatab ta aga hea meelega...

${ }^{35}$ Miks taastatud Eesti Vabariigi kultuurbürokraadid ei esitanud ka väliseesti lauluja tantsupidusid UNESCOle, on muidugi omaette küsimus, mida ei ole kodueesti ühiskonda kogenud väliseestlastel raske seletada. Vt käesoleva artikli sissejuhatust.

\section{Allikad}

Laasik, Andres 2008a. Laulutaadi hümnid. ETV 2008.

Laasik, Andres 2008b. ERR Uudised,10.12.2008.

Säde, Rein, 2007. Tuulepealsed leelod. Dokumentaalfilm. PROfilm 2007.

Ado Valge meil autorile, autori valduses.

Eerik-Niiles Krossi meil autorile, autori valduses.

Triinu Ojamaa meilid autorile aastaist 2011-2015, autori valduses.

\section{Kirjandus}

Aarma, Jüri 2014. Kuno Areng: Gustav Ernesaks õpetas mind suuri jamasid vältima. Maaleht 27, 3. juuli, lk 24-25.

Aavik, Juhan 1965-1969. Eesti muusika ajalugu I-IV. Stockholm: Eesti Lauljaskond Rootsis \& Uppsala: Arostryck.

Allandi, Marge 2014. Kolm tuld: Jüriöö, võidupüha, laulupidu. Ajalooline Ajakiri 2/3 (148/49), lk 173-206 (doi: 10.12697/AA.2014.2-3.02).

Arjakas, Küllo 2012. Eesti hümn. Tallinn: Menu kirjastus.

Aun, Karl 1975. Eestlaste suurüritused. Kurlents, Alfred \& Antik, Richard \& Olvet, Jaan (toim). Eestlased Kanadas. Ajalooline koguteos. Toronto: Kanada Eestlaste Ajaloo Komisjon.

Aun, Karl 1985. Eestluse suursündmused. Pekomäe, Vello \& Pettai, Elmar (toim). ESTO84 Toronto. Tähtraamat. Stockholm: Välis-Eesti \& EMP.

Brüggemann, Karsten \& Kasekamp, Andres 2014. Singing oneself into a nation? Estonian Song festivals as rituals of political mobilisation. Nations and Nationalism 20 (2) (http://dx.doi.org/10.1111/nana.12059).

Eesti saatusaastad 1863-1972 = Maasing, Richard \& Kauri, Hans \& Purre, Arnold \& Üürike, Madis \& Jürima, Ülo (toim). Eesti saatusaastad 1945-1960 I-VI. Stockholm: EMP. 
EK(b)P KK VIII = EK(b)P Keskkomitee VIII pleenumi stenogramm. Akadeemia 1998 (12), lk 2655-2686; 1999 (1), lk 191-222; 1999 (2), lk 415-446; 1999 (3), lk 639-670; 1999 (4), lk 863-894; 1999 (5), lk 1087-1118; 1999 (6), lk 1311-1342; 1999 (7), lk 1535-1566; 1999 (8), lk 1759-1790; 1999 (9), lk 2017-2048; 1999 (10), lk 2221-2256.

Ernesaks, Gustav 1977. Nii ajaratas ringi käib. Tallinn: Eesti Raamat.

ER NL SI 1971 = Lentsman, Leonid (peatoim) 1971. Eesti rahvas Nõukogude Liidu Suures Isamaasõjas 1941-1945. Tallinn: Eesti Raamat.

ERR II MS 1954-1908 = Maasing, Richard \& Blumfeldt, Evald \& Kauri, Hans \& Pekomäe, Vello \& Paju, Otto (toim) 1954-1980. Eesti riik ja rahvas II maailmasõjas I-XII. Koguteos. Stockholm: EMP.

ERR II MS 1964-1968 = Eesti riik ja rahvas Teises maailmasõjas 11.-13. Tallinn: Kodumaa.

Meikop, Kristjan \& Remmelgas, Jüri \& Äro, Johannes (toim) 1970. VI Eesti üldlaulupidu Rootsis. Eesti üldlaulupidude 100-aasta juubeli tähistamiseks 24. mail 1969. a. Stockholmis. Stockholm: Eesti Lauljaskond Rootsis.

Grabbi, Hellar 2010. Seitse retke isamaale. Mälestuslikud esseed. Tartu: Ilmamaa.

Grabbi, Hellar 2011. Pagulaskirjanduse ajalugu veel ühe pilgu läbi. Vaade Välis-Eestist. Keel ja Kirjandus 1, lk 48-54.

Inno, Kersti 1999. Kuno Areng. Tallinn: Avita.

Johansson, Björn 1967. Kultiverad råsång. Göteborgs Handels- och Sjöfartstidning, sept. keskel.

Jürjo, Indrek 1996. Pagulus ja Nõukogude Eesti. Vaateid KGB, EKP ja VEKSA arhiivdokumentide põhjal. Tallinn: Umara.

Kangro, Bernard 1976a. Eesti Rootsis. Lund: Eesti Kirjanike Kooperatiiv.

Kangro, Bernard 1976b. Estland i Sverige. Lund: Eesti Kirjanike Kooperatiiv.

Kiin, Sirje 2009. Marie Under. Elu, luuletaja identiteet ja teoste vastuvõtt. Tallinn: Tänapäev.

Kiisk, Harri 1965. Eesti laulupidudest enne ja nü̈̈. Lund: Tulimuld.

Kiisk, Harri 1967. Körsången i Estland. Stockholm: Estniska Nationalfonden.

Kiisk, Harri 1982. Tuudur Vettik'u saatusest okupatsioonide ajal. Volga burlakkide laulust sai "Laul Leninist". Teataja (Stockholm) 26. juuni, lk 6-8.

Klaats, Erika 2004. Kuno Areng: Dirigendi redel on väga pikk. Maaleht 22. juuli, lk 18-19.

Kool, Ferdinand 1999. DP Kroonika: Eesti pagulased Saksamaal 1944-1951. Lakewood, NJ: Eesti Arhiiv Ühendriikides.

Kreem, Robert 1998. ESTO tee Torontost Tallinna. Eestlaste elujõu ja vabadusaate aastad 1972-1996. Eesti Entsüklopeediakirjastus, Tallinn.

Kross, Jaan 2013. Kallid kaasteelised. Tallinn: Eesti Keele Sihtasutus.

Kuuli, Olaf 2002. Sula ja hallad Eesti NSVs. Kultuuripoliitikast aastail 1953-1969. Tallinn: O. Kuuli. 
Kuutma, Kristin 1996. Laulupeod rahvusliku identiteedi kandjana. Mäetagused 1-2, lk 80-94 (doi: 10.7592/MT1996.01/02.internet).

Kuutma, Kristin 1997. Kultuuriidentiteet, rahvuslus ja muutused laulutraditsioonis. Mäetagused 7, lk 45-56 (doi: 10.7592/MT1998.07.kuutma).

Kuutma, Kristin 1998. Festival as communicative performance and celebration of identity. Folklore 7, lk 79-86 (doi: 10.7592/FEJF1998.07.festiva).

Labi, Kanni 2011. Isamaalaulud ja okupatsioonirežiim - nostalgia, utoopia ja reaalsus. Methis 7. Studia Humaniora Estonica. Nõukogude aja erinumber, lk 109-121.

Lepik, Kalju (toim) 1981. Põldma, Alfred (koost). ESTO $80=$ Estonian World Festival: III Ülemaailmsed Eesti Päevad Stokholmis 6. juulist - 13. juulini 1980. Stockholm: ESTO Peakomitee.

Liivik, Olev 2009. Persecution of Jews in Estonia in the late 1940's and early 1950's. Estonia since 1944. Hiio, Toomas \& Maripuu, Meelis \& Paavle, Indrek (toim). Reports of the Estonian International Commission for Investigation in Crimes Against Humanity. Tallinn: Inimsusevastaste Kuritegude Uurimise Eesti Sihtasutus.

Lippus, Urve 2007. Meestelaulu traditsioon Eestis. Lisa RAM-i repertuaar 1945-1962. Meeskoor ja meestelaul = Männerchor und Männergesang. Eesti Muusikaloo toimetised 8. Tallinn: EMTA.

Lääne-Rootsi eestlaste suvipäev Hindåsis 1946. Borås Civiltryckeriet.

Meikop, Kristjan \& Remmelgas, Jüri \& Äro, Johannes (toim) 1969. VI Eesti Üldlaulupidu Rootsis. Eesti üldlaulupidude 100-aasta juubeli tähistamiseks 24. mail 1969. a. Stockholm: Eesti Lauljaskond Rootsis.

Meri, Hendrik-Peeter 2008. Tagasivaateid veerevast vagunist. Tartu: Ilmamaa.

Ojamaa, Triinu 2011. 60 aastat eesti koorilaulu multikultuurses Torontos $=60$ years of Estonian choral singing in multicultural Toronto. Tartu: Eesti Kirjandusmuuseumi Teaduskirjastus.

Ojamaa, Triinu 2012. Harri Kiisk - Eesti kultuurivahendaja Rootsis. Tartu: Eesti Kirjandusmuuseumi Teaduskirjastus.

Ojaveski, Toivo \& Puust, Mart \& Põldmäe, Alo, 2012. 130 aastat Eesti laulupidusid. Tallinn: Talmar \& Põhi.

Põldmäe, Alo \& Põldmäe, Mare (koost) 1988. Eesti isamaalisi laule. Tallinn: Eesti Raamat.

Päts, Riho (koost) 1942. Lemmiklaulik. Algkooli I ja II klassi lauluvara. Tallinn: Eesti Kirjastus.

Randjärv, Laine 2012. Sillad üle piiride. Tuudur Vettiku kirjad abikaasa Lonni Paigaline-Vettikule aastatel 1955-1956. Tuudur Vettiku ja Roland Laasmäe kirjavahetus aastatel 1959-1975. Tallinn: SE\&JS.

Randjärv, Laine 2013. Loovisiksuse roll Eesti laulupeoliikumises aastatel 1940-1980. Tuudur Vettiku ja Roland Laasmäe epistolaarse pärandi põhjal. Tartu: Tartu Ülikooli Kirjastus. 
Rebas, Hain 1978. Beroende och opposition. En studie i 1950-talets sovjet-estniska historieskrivning. Historisk Tidskrift 4/ 1978 (Stockholm), lk 417-439.

Rebas, Hain 2005. Dependence and Opposition. Problems in Soviet Estonian Historiography in the late 1940's and early 1950's. Journal of Baltic Studies 36 (4), (New York) Winter, lk 423-448.

Remsu, Olev 2009. Seest siiruviiruline, pealt punakarvaline. Sirp 6. veebruar http:// www.sirp.ee/s1-artiklid/film/seest-siiruviiruline-pealt-punakarvaline/ - 4. aprill 2016).

Saueauk, Meelis 2015. Propaganda ja terror. Nõukogude julgeolekuorganid ja Eestimaa Kommunistlik Partei Eesti sovetiseerimisel 1944-1953. Tallinn. SE\&JS.

Toi, Roman 2007. Kaunimad laulud pühendan sull'. Roman Toi mälestused. TorontoViljandi: T. Sarv.

Tuglas, Elo 1993. Elukiri. [Päevik 1952-1958.] Tallinn: Faatum.

Valk, Heinz 2010. Pääsemine helgest tulevikust. Tallinn: Kunst.

Veskimägi, Karl-Olev 2005. Kuidas valitseti Eesti NSV-d. Eestimaa Kommunistliku Partei Keskkomitee büroo 162 etteastumist 1944-1956 vahemängude ja sissejuhatusega. Tallinn: Varrak.

Välme, Rein \& Milits, Alex 1980. ESTO-80 = Estnisk Världsfestival = Estonian World Festival = Estnische Weltfestspiele $:$ Stockholm 6.-13. VII 1980: Ülemaailmsed Eesti Päevad. Stockholm: Välis-Eesti \& EMP.

\section{Summary}

\section{Split in Estonian choir singing in the Soviet period}

\section{Hain Rebas}

Keywords: Estonian diaspora, Gustav Ernesaks, Harri Kiisk, Juhan Aavik, Roman Toi, song festival

In Estonia the notion of Estonian song festivals has become synonymous with the name of beloved composer and conductor Gustav Ernesaks (1908-2003). The reasons for this are both unplanned and purposeful, both simple and complex.

In marked contrast, the song festivals are not even peripherally associated with the traditions and conductors outside of Soviet-occupied Estonia, who were in many ways the custodians of qualified and non-Sovietised Estonian choir music. Prominent figures such as Juhan Aavik, Eduard Tubin, and Tuudur Vettik, followed by their students Harri Kiisk in Sweden and Roman Toi in Canada, promoted the democratic and freedom-oriented Estonian Song Festival tradition in Sweden, Germany, Canada, and the US for half a century and from 1972 onwards also in transnational ESTO festivals.

It is generally maintained that the Estonian diaspora played a distinctive role in the dismantling of Soviet rule in Estonia a quarter-century ago. Consequently, we must accept that song festivals held outside of Estonia effectively kept the spirit of a free 
Estonia alive. It is therefore time to harmonise the Ernesaks' excluding phenomenon pertaining to song festivals since World War II with the efforts of Estonian master conductors in Germany, Sweden, Canada, and the US. Their accomplishments far away in the Free World added significantly to the present-day song festival tradition that grows ever stronger in Estonia. It is compellingly clear that the Estonian diaspora song and ESTO festivals should be included in the Estonian paragraph of the 2003 UNESCO World Heritage List.

And, if one looks around on the Song Festival Grounds in Tallinn, one easily discovers space enough for Dr Roman Toi of Toronto (b. 1916) beside the statue of Maestro Gustav Ernesaks. 